\title{
The effect of beans types and soaking time on the characteristics of Indonesian traditional food "Instant Bose"
}

\author{
Lista EKA YULIANTI ${ }^{*}$ (D), Woro SETIABOMA, Ainaya NURRACHMA HAKIM², Esti WIDOWATI ${ }^{2}$, \\ Nok AFIFAH ${ }^{1}$, Riyanti EKAFITRI ${ }^{1}$
}

\begin{abstract}
Bose is a traditional Indonesian food made from a mixture of corn grits and beans that are cooked for a long time. Bose has the potential to be processed into instant food. This study aims to examine the effect of adding several types of beans (soybeans, mungbeans, and peanuts) and the length of soaking time (2,9, and 16 hours) on the physicochemical and sensory properties of instant Bose. A completely randomized design was used in this study. Instant Bose with the addition of soybeans had the highest protein and iron content, while instant Bose with the mungbeans addition had the highest carbohydrate content. The addition of peanuts in instant Bose resulted the highest fat content, the longest rehydration time and the highest hardness compared to the other treatments. The longer soaking time decreased the nutritional value of instant Bose, speeded up rehydration time, increased swelling volume, and decreased hardness. Based on the sensory analysis, instant Bose made from a mixture of soybeans with the soaking time of 16 hours showed the highest preference. This kind of Bose contained $15.32 \%$ protein, $4.85 \%$ fat, and $1.85 \%$ iron with a rehydration time of 8.38 minutes and a hardness of $664.24 \mathrm{~N}$.
\end{abstract}

Keywords: Instant Bose; beans; soaking time; traditional food.

Practical Application: Instant traditional food with short cooking times and amount of nutrients

\section{Introduction}

As a large country, Indonesia is rich in various ethnic groups with a wide variety of traditional foods. One of the traditional foods is Bose. Bose is a type of local food originating from East Nusa Tenggara, Indonesia. The main raw material for making this food is cereals in the form of white corn grits, which is commonly used as a substitute for rice (Gasong et al., 2018). The preparation of this traditional Bose corn takes quite a long time (more than 4 hours), which includes mixing corn grits with beans, boiling corn grits and beans until they become soft, then adding coconut milk to be consumed immediately (Gasong, 2019; Rosyid, 2014).

The type of corn commonly used in the manufacture of Bose is waxy white corn (Zea mays ceritina) with additional beans such as rice beans (Vigna umbellata) and cowpeas (Vigna unguliculata (L.). Waxy white corn and the other two types of beans are included in the types of local beans from East Nusa Tenggara (Yasin et al., 2014). According to Ishartani et al. (2019) white corn is a source of carbohydrates with high dietary fiber $(12-15 \%)$ and low glycemic index $(28.66-41,37)$ Meanwhile, according to Bhagyawant et al. (2019) rice beans are the source of vegetable protein with high protein and antioxidant contents, namely $2.88-31.79 \%$ and $9.36-18.56 \%$ respectively. Cowpeas are also the source of protein (24.4\%), high carbohydrate (45.64-57.12\%) and minerals such as calcium, iron, and zinc
(Gondwe et al., 2019; Verma et al., 2019). The combination of those cereals in Bose complements the nutritional value of the product. According to Puspita et al. (2017), the nutritional contents of Bose corn per 100 grams are 29.27 grams of carbohydrates, 5.79 grams of protein, and 4.97 grams of fat. In addition to mixing waxy corn grits with rice beans and cowpeas, in some other areas in Indonesia, several types of beans such as soybeans, mungbeans and peanuts are also used as a mixture in Bose processing. According to Balasubramanian et al. (2012), currently, the combination of cereals and legume-based foods is increasingly popular to complement each other in terms of protein and digestible carbohydrate profiles. It results in new food product with higher nutritional quality.

Bose processing requires a relatively long time, which is more than 4 hours (Rosyid, 2014), so that it is not suitable for the current lifestyle of society. Nowadays, people's lifestyles have changed, where people are busy and have fast movements, including their daily food preparation (Sasmitaloka et al., 2019; Srichamnong et al., 2016). Therefore, it is important to develop the way to process it in order to shorten the processing time of Bose into an instant product. With a shorter cooking time, instant Bose is expected to become a famous product in the recent years. Similar research is conducted in the manufacture of diamond rice consisting of several stages, namely soaking

${ }^{1}$ Research Center for Appropriate Technology, Indonesian Institute of Sciences, West Java, Indonesia

${ }^{2}$ Department of Food Science and Technology, Faculty of Agriculture, Universitas Sebelas Maret, Surakarta, Indonesia

*Corresponding author: listaeka0507@gmail.com 
with Na-citrate solution, cooking, pretreatment before drying, drying, and rehydration (Prapluettrakul et al., 2012). Meanwhile, the making of instant corn, according to Kumalasari et al. (2018), includes the stages of washing, soaking, drying, steaming, cooling, freezing, thawing, and drying. One of the steps that affect the instantiation process is soaking. According to (Balasubramanian et al., 2012), soaking before cooking can reduce the cooking time. As the hydration soaking increases, higher water diffusion occurs, causing an increase in grains dimensions, leading to the swelling of the starch granules, and widening of cracks in the grains due to the diffusion of water, resulting in more puffed kernels. When the soaked grains are cooked and dried, water vapor expansion will occur, which results in more expanding kernels. During the drying process, case hardening can occur, which blocks the release of water vapor. It results in an expanding grain structure that is larger in the middle, allowing the rehydration process easier (Prasert \& Suwannaporn, 2009). According to Fernandes et al. (2010), it also affects the nutritional value of grains, namely reducing the protein content of grains but increasing bioavailability and reducing the queuing content of nutrients. The soaking process is useful in the production of children's food products with high protein digestibility and mineral availability (Eltayeb et al., 2017).

So far, research related to Bose is still limited, including regarding the development of instant Bose corn products enriched with iron to treat anemia in adolescent girls, and studies on the level of preference for instant Bose in Kupang, East Nusa Tenggara (Gasong, 2019; Gasong et al., 2018). There are no studies that have examined the effect of the type of beans and soaking time on the quality of instant Bose. Therefore, this study aims to determine the physicochemical and organoleptic properties of instant Bose that are influenced by the addition of several types of beans (soybeans, mungbeans, and peanuts) and the length of soaking time in the instantiation process. The results of this study are expected to produce an instant Bose product with nutritional quality, short rehydration time, and consumer preferences.

\section{Materials and methods}

\subsection{Materials}

The main ingredients used in this study were white corn grits, rice beans, cowpeas, soybeans, mungbeans, peanuts, and sodium citrate. White corn, rice beans, and cowpeas were obtained from East Nusa Tenggara, Indonesia. Meanwhile, soybeans, mungbeans, peanuts, and sodium citrate were obtained from the local market in Subang, West Java.

\subsection{Methods}

\section{Instant Bose preparation}

As much as $60 \%$ white corn grits, $13.33 \%$ cowpeas, and $13.33 \%$ rice beans with variations in the addition of other beans as much as $13.33 \%$, each of which was mixed and soaked in $1 \% \mathrm{Na}$-citrate solution. After that, the mixture was added with corn-beans and water at a ratio of 1:10 until the water was completely absorbed by the corn and beans. Furthermore, the pressure cooking process was carried out for 30 minutes followed by freezing for 16 hours, thawing, and drying until the instant Bose was obtained, which was then ready to be rehydrated. The treatment in this study included the addition of several types of beans, namely soybeans, mungbeans, and peanuts, and the various lengths of soaking time in Na-citrate solution, namely 2,9 , and 16 hours.

\section{Chemical analysis}

Chemical analysis carried out on dry Bose samples included moisture, ash, protein, fat, carbohydrate, and iron content. The procedure to test these parameters refered to SNI 01-2891-1992 (The National Standardization Agency of Indonesia, 1992) concerning the analytical methods for food and beverage.

\section{Physical analysis}

Physical analysis carried out included bulk density, dehydration ratio, and expansion volume, which refers to Kumalasari et al. (2018), rehydration time (Bui \& Coad, 2015), and hardness (Prasert \& Suwannaporn, 2009) with modifications. A total of 10 grams of rehydrated Bose samples were molded in the form of a tube with a size of $1 \mathrm{~cm}$ of height and $1.5 \mathrm{~cm}$ of diameter. After then, the sample was pressed with probe $\mathrm{P} 36$, with a pretest speed of $2.00 \mathrm{~mm} / \mathrm{s}$, a test speed of $1.7 \mathrm{~mm} / \mathrm{s}$, a post test speed of $1.00 \mathrm{~mm} / \mathrm{s}$, a strain of $30 \%$, and a trigger force of $5.0 \mathrm{gr}$.

\section{Sensory analysis}

Sensory analysis was performed using a hedonic rating test with a scale of 1 (strongly dislike) -7 (strongly like) on the parameters of color, aroma, taste, texture, and overall acceptance. This sensory analysis was carried out on 30 untrained panelists. The sample of Bose being tested was rehydrated Bose ( 75 grams, Bose in $500 \mathrm{ml}$ of water) that was cooked according to the rehydration time.

\section{Statistical analysis}

This study used a completely randomized design to evaluate the effect of adding several types of beans and soaking time on the physicochemical quality of Bose. Each treatment was repeated three times and two replications of the analysis. Based on the psychochemical properties, then the best treatments for every bean type were selected based on the effectiveness index method (DeGarmo et al., 1984). The choosen treatments were then examined by sensory analysis, and compared with conventional Bose samples. All data obtained were analyzed using ANOVA analysis of variance at $95 \%$ confidence interval. If there is a significant difference, the A Duncan's Multiple Range Test ( $\alpha=$ $5 \%$ ) will be conducted.

\section{Results and discussion}

\subsection{Chemical properties}

The nutritional content of instant Bose (moisture, ash, protein, fat, carbohydrate, and iron content) in various traetments can be 
seen in Table 1 . The moisture content of all variations of instant Bose ranged from 5.47-6.76\% (Table 1). This water content was close to the water content of instant rice products according to Sasmitaloka et al. (2019), namely 6.60-7.67\%. This water content was lower than $14 \%$, so it could prevent microbiological damage (Phukasmas \& Songsermpong, 2019). The several types of beans and the length of soaking time had a significant effect on the moisture content parameter $(\mathrm{p}<0.05)$. The types of beans with the same soaking time showed no significant difference in moisture content, meanwhile the longer the soaking time, the lower the instant Bose water content was. This was similar to the results of research conducted by Eltayeb et al. (2017), which states that the soaking process reduces the water content of sorghum cereal.

The ash contents of all variations of instant Bose ranged from $1.59-1.85 \%$ (Table 1 ). Those values were higher than that of fibrous instant corn, which is $1.04 \%$ (Ekafitri et al., 2016). The values of ash content have a tendency to be the same as the values of water content, where the types of beans at the same soaking time showed the non-significantly different values of ash content, meanwhile the longer of soaking time, the lower the instant Bose ash content was. This is in line with Fernandes et al. (2010) and Narsih et al. (2012) suggested that the longer soaking time reduces the ash content in sorghum seeds and common beans caused by mineral lixiviation and decreases of anti-nutrients that can chealate minerals during soaking. ElMaki et al. (2007) found that increasing soaking time of beans or discarding the soaking water results in greater loss of minerals.

The type of beans and the length of soaking time had a significant effect on the protein content of instant Bose $(\mathrm{p}<$ 0.05). Instant Bose with the addition of soybeans had the highest protein content (15.32-16.04\%) compared to instant Bose with the addition of mungbeans (13.32-13.90\%) and peanuts (14.39\%$14.86 \%)$. The high protein content in Bose with the addition of soybeans is due to the fact that soybeans have a higher protein content (36.56-39.70\%) than mungbeans (25.99-26.56\%) and peanuts (25.07-28,20\%) (Gunathilake et al., 2016). The longer the soaking time, the lower the protein content of instant Bose treated with the three kinds of additions of beans. This result is similar to that expressed by (Fernandes et al., 2010; Widjajaseputra et al., 2019). The decrease in protein content is due to the increasing number of leaching of soluble protein into the soaking water (Widjajaseputra et al., 2019).

The beans type and soaking time also had a significant effect on the fat content of instant Bose $(\mathrm{p}<0.05)$. The highest fat content was produced in instant Bose with the addition of peanuts, namely $8.57-8.97 \%$, and instant Bose with the lowest fat content resulted from the addition of mungbeans, namely $2.35-2.63 \%$. This is because peanuts contain high fat, namely $46.73 \%$, while mungbeans contain low fat, which is $3.70 \%$ (Wikandari et al., 2020). The longer the soaking time, the lower the fat content of instant Bose was. This is in line with the statement of Eltayeb et al. (2017) and Narsih et al. (2012) concerning soaking sorghum seeds. According to Eltayeb et al. (2017), soaking process can decrease the fat content due to the absorption of water, which leads to the activation of enzyme and digestion of food reserves. However, Narsih et al. (2012) stated that the decrease in fat in sorghum seeds is due to the entry of water after the enzyme is activated, the entry of the endosperm, and the digestion of food reserves. The lipase enzyme breaks down fat into glycerin and water-soluble fatty acids, so it can diffuse into cell tissue.

The type of beans and the length of soaking time also had a significant effect on the levels of carbohydrates of instant Bose ( $p$ $<0.05$ ). The highest carbohydrate content was produced in instant Bose with the addition of mungbeans (74.88-76.89\%), followed by soybeans (69.89-72.36\%) and peanuts (68.23-69.71\%). This is because mungbeans have the highest carbohydrate content compared to peanuts and soybeans. According to Wikandari et al. (2020) mungbeans, soybeans, and peanuts have carbohydrate content of $69.82 \%, 29.82 \%$, and $8.81 \%$ respectively. The longer the soaking time, the higher the carbohydrate content of instant Bose will be (Table 1). This is not in accordance with the results of research by Fernandes et al. (2010) and Narsih et al. (2012) which stated that the soaking process reduces the carbohydrate content. The carbohydrate content of instant Bose is calculated using different methods. This study determined carbohydrate by difference to other proximate components. If the levels of other components decrease along with the treatment carried out, the carbohydrate content will be even higher. In this treatment, the longer the soaking time, the lower the water, ash, protein, and fat content would be, thereby increasing the carbohydrate content of instant Bose.

Table 1. Chemical properties of instant Bose $e^{*}$.

\begin{tabular}{|c|c|c|c|c|c|c|c|}
\hline Types of beans & $\begin{array}{l}\text { Soaking time } \\
\text { (hour) }\end{array}$ & $\begin{array}{c}\text { Moisture content } \\
(\%)\end{array}$ & $\begin{array}{l}\text { Ash content } \\
\text { (\%) }\end{array}$ & $\begin{array}{c}\text { Protein content } \\
(\%)\end{array}$ & $\begin{array}{c}\text { Fat content } \\
\quad(\%)\end{array}$ & $\begin{array}{c}\text { Carbohydrate content } \\
(\%)\end{array}$ & $\begin{array}{l}\text { Iron content } \\
(\mathrm{mg} / 100 \mathrm{~g})\end{array}$ \\
\hline \multirow{2}{*}{ Soybeans } & 2 & $6.63 \pm 0.31^{b}$ & $1.85 \pm 0.06^{\mathrm{d}}$ & $16.04 \pm 0.21^{\mathrm{f}}$ & $5.60 \pm 0.02^{\mathrm{e}}$ & $69.89 \pm 0.38^{b}$ & $2.01 \pm 0.12^{\mathrm{e}}$ \\
\hline & 16 & $5.79 \pm 0.30^{\mathrm{a}}$ & $1.68 \pm 0.04^{\mathrm{ab}}$ & $15.32 \pm 0.07^{\mathrm{e}}$ & $4.85 \pm 0.02^{\mathrm{d}}$ & $72.36 \pm 0.41^{\mathrm{d}}$ & $1.85 \pm 0.08^{\text {cde }}$ \\
\hline \multirow[b]{2}{*}{ Mungbeans } & 2 & $6.76 \pm 0.31^{b}$ & $1.83 \pm 0.10^{\mathrm{cd}}$ & $13.90 \pm 0.08^{b}$ & $2.63 \pm 0.04^{c}$ & $74.88 \pm 0.32^{\mathrm{e}}$ & $1.95 \pm 0.10^{\mathrm{de}}$ \\
\hline & 9 & $6.12 \pm 0.42^{\mathrm{ab}}$ & $1.73 \pm 0.06^{\mathrm{bcd}}$ & $13.43 \pm 0.06^{\mathrm{a}}$ & $2.55 \pm 0.02^{b}$ & $76.17 \pm 0.36^{\mathrm{f}}$ & $1.69 \pm 0.10^{b c}$ \\
\hline \multirow{3}{*}{ Peanuts } & 2 & $6.17 \pm 0.31 \mathrm{ab}$ & $1.78 \pm 0.08 \mathrm{bcd}$ & $14.86 \pm 0.08^{\mathrm{d}}$ & $8.97 \pm 0.01^{\mathrm{h}}$ & $68.23 \pm 0.17^{a}$ & $1.82 \pm 0.24^{\text {cde }}$ \\
\hline & 9 & $6.07 \pm 0.42^{\mathrm{ab}}$ & $1.72 \pm 0.08^{b c}$ & $14.75 \pm 0.18^{\mathrm{d}}$ & $8.57 \pm 0.02^{f}$ & $68.89 \pm 0.24^{a}$ & $1.76 \pm 0.01^{\mathrm{bcd}}$ \\
\hline & 16 & $5.47 \pm 0.44^{\mathrm{a}}$ & $1.59 \pm 0.02^{\mathrm{a}}$ & $14.39 \pm 0.11^{c}$ & $8.84 \pm 0.05^{g}$ & $69.71 \pm 0.40^{b}$ & $1.39 \pm 0.14^{\mathrm{a}}$ \\
\hline
\end{tabular}

${ }^{\star}$ Mean values with different superscript on the same column are significantly different $(p<0.05)$. 
Iron $(\mathrm{Fe})$ content of instant Bose ranged from 1.39-2.01 mg/100 $\mathrm{g}$ (Table 1). The highest average iron content was produced in the Bose treatment with the addition of soybeans, followed by mungbeans and peanuts. The difference in iron levels in instant Bose is influenced by difference in the iron content of each added bean. According to Gunathilake et al. (2016), soybeans contain quite high iron, namely 7.91-11.6 mg/100 g, while mungbeans averagely contain $5.9 \mathrm{mg} / 100 \mathrm{~g}$ (Dahiya et al., 2015), and peanuts contain at $4.71 \mathrm{mg} / 100 \mathrm{~g}$ (Wikandari et al., 2020). The longer the soaking time, the lower the iron content of instant Bose was. According to El-Adawy et al. (2000), soaking beans in $\mathrm{NaHCO}_{3}$ reduces $\mathrm{Fe}$ content due to the replacement of $\mathrm{Na}$ instead of $\mathrm{Ca}$, $\mathrm{Zn}$ and Fe during soaking. Na in the soaking solution affects the concentration of minerals in the beans. Soaking beans in $\mathrm{Na}-$ citrate caused a decrease in Fe content in this study presumably for the same reason. The Fe content of instant Bose is $1.91 \mathrm{mg} / 100$ gr (Gasong, 2019), which is lower than the Fe content in instant Bose with the addition of soybeans in the length of soaking time of 2 and 9 hours and mungbeans in the length of soaking time of 2 hours in this study. This means that the addition of beans increases the Fe content in instant Bose.

\subsection{Physical properties}

The physical content of instant Bose (bulk density, rehydration time, rehydration ratio, volume expansion, and hardness) in various treatments can be seen in Table 2. Bulk density is one of the important physical properties of instant product because it relates to product packaging and transportation. It is determined by the ratio between the weight of material and volume $(\mathrm{g} / \mathrm{ml})$. Bulk density is affected by the type of material, water content, shape and size of the material. Bulky material is the material that has low bulk density, meaning that the light material requires a large space. The lower the density of the material, the more porous the material is.

Bulk density of instant Bose (Table 2) ranged from 0.35 to $0.50 \mathrm{~g} / \mathrm{ml}$. Instant Bose that was soaked for 16 hours had the lower bulk density than instant Bose soaked for 2 or 9 hours. These results indicated that the longer soaking time in the sodium citrate solution, the more porous the material will be. According to (Husain et al., 2006), soaking corn rice in sodium citrate solution can disrupt and breakdown the protein structure and it causes the corn grains become porous. Instant Bose that was soaked for 16 hours with addition of soybeans and mungbeans had the lower bulk density than instant Bose that was added with peanuts. These results indicated that instant
Bose added with peanuts had lower porosity than instant Bose added with other types of beans. Peanuts have high fat content (Wikandari et al., 2020) that can inhibit water absorption during instantiation process. According to (Bourlieu-Lacanal et al., 2007), lipids usually act as moisture barriers because of their polar nature, and these hydrophobic substances are capable of forming a water-impervious structure and reduce the water transfer efficiently. This causes the peanut pores to be difficult to open and the porosity to be low.

Instant food is a food product which can be served in a relatively short time. Therefore, the rehydration time is the main parameter of a food product to be classified as an instant product. Based on Table 2, it is seen that instant Bose, which had the shorter rehydration time, was produced by soaking for 16 hours with the addition of soybeans ( $8.38 \mathrm{~min}$ ) and mungbeans ( $8.32 \mathrm{~min})$. Soaking the beans in sodium citrate solution for 16 hours can break the protein structure better than soaking them for 2 and 9 hours. This is in line with the research results obtained by Leahu \& Rosu (2014) that the length of cooking time of dry common beans significantly is reduced by soaking the beans in sodium bicarbonate solution. According to Luna et al. (2015) soaking rice in sodium citrate solution can destroy or decompose the protein structure. This makes the beans to be more porous and readily absorb the water, so it shortens the rehydration time. Instant Bose with addition of peanuts had the longest rehydration time than other additions of beans. High fat content in peanuts can inhibit the water transfer process required during instantiation. This can affect the physical properties of instant Bose.

The rehydration ratio shows the reabsorption of water by the dry products. High rehydration ratio is desirable for dry products. Rehydration ratio of instant Bose (Table 2) ranged from 3.13 to $3.82 \mathrm{~g} / \mathrm{g}$. Rehydration ratio is negatively correlated with bulk density (Prasert \& Suwannaporn, 2009). The longer soaking time, the higher the rehydration ratio of instant Bose was. Instant Bose that was soaked for 16 hours with the addition of soybeans and mungbeans had the highest rehydration ratio. Soaking corn rice in sodium citrate solution can disrupt and breakdown the protein structure (Husain et al., 2006). Rehydration of dried foods involves a sequence of events: wetting of the surface, penetration of the water into the pores, adsorption on the surface of the matrix, diffusion into the solid matrix and equilibration (Berk, 2009). The higher bulk density and the longer rehydration time in instant Bose with addition of peanuts indicated that the pores were not open, so the water penetration cannot occur optimally. This results in a lower rehydration ratio of instant Bose with the addition of peanuts.

Table 2. Bulk density, rehydration time, rehydration ratio, volume expansion, hardness of instant Bose*.

\begin{tabular}{|c|c|c|c|c|c|c|}
\hline Types of beans & $\begin{array}{c}\begin{array}{c}\text { Soaking time } \\
\text { (hour) }\end{array} \\
\end{array}$ & $\begin{array}{l}\text { Bulk density } \\
(\mathrm{g} / \mathrm{ml})\end{array}$ & $\begin{array}{c}\text { Rehydration time } \\
\text { (min) }\end{array}$ & $\begin{array}{c}\text { Rehydration ratio } \\
(\mathrm{g} / \mathrm{g})\end{array}$ & $\begin{array}{c}\text { Volume expansion } \\
(\%)\end{array}$ & $\begin{array}{l}\text { Hardness } \\
(\mathrm{N})\end{array}$ \\
\hline \multirow{3}{*}{ Soybeans } & 2 & $0.47 \pm 0.01^{\mathrm{d}}$ & $14.23 \pm 0.08^{\mathrm{d}}$ & $3.27 \pm 0.10^{\mathrm{b}}$ & $111.57 \pm 11.14^{\mathrm{ab}}$ & $760.81 \pm 37.52^{a}$ \\
\hline & 9 & $0.43 \pm 0.02^{c}$ & $11.17 \pm 0.08^{c}$ & $3.47 \pm 0.09^{\mathrm{cd}}$ & $117.39 \pm 9.70^{\mathrm{ab}}$ & $733.54 \pm 34.30^{\mathrm{a}}$ \\
\hline & 16 & $0.36 \pm 0.01^{a}$ & $8.38 \pm 0.03^{a}$ & $3.71 \pm 0.16^{\text {ef }}$ & $122.22 \pm 22.22^{\mathrm{b}}$ & $680.99 \pm 24.66^{\mathrm{a}}$ \\
\hline \multirow{3}{*}{ Mungbeans } & 2 & $0.46 \pm 0.01^{d}$ & $14.18 \pm 0.08^{\mathrm{d}}$ & $3.35 \pm 0.10^{b c}$ & $107.87 \pm 6.85^{\mathrm{ab}}$ & $890.68 \pm 40.65^{b}$ \\
\hline & 9 & $0.42 \pm 0.00^{b c}$ & $10.30 \pm 0.05^{\mathrm{b}}$ & $3.59 \pm 0.06^{\mathrm{de}}$ & $115.74 \pm 13.70^{a b}$ & $859.30 \pm 52.26^{b}$ \\
\hline & 16 & $0.35 \pm 0.01^{\mathrm{a}}$ & $8.32 \pm 0.10^{\mathrm{a}}$ & $3.82 \pm 0.04^{\mathrm{f}}$ & $118.52 \pm 6.42^{\mathrm{b}}$ & $687.13 \pm 28.29^{\mathrm{a}}$ \\
\hline \multirow{3}{*}{ Peanuts } & 2 & $0.50 \pm 0.02^{\mathrm{f}}$ & $24.22 \pm 0.08^{g}$ & $3.13 \pm 0.08^{a}$ & $95.83 \pm 7.22^{\mathrm{a}}$ & $1192.63 \pm 91.99^{\circ}$ \\
\hline & 9 & $0.46 \pm 0.01^{\mathrm{d}}$ & $22.27 \pm 0.10^{\mathrm{f}}$ & $3.33 \pm 0.06^{b c}$ & $100.37 \pm 10.56^{\mathrm{ab}}$ & $1093.83 \pm 94.53$ \\
\hline & 16 & $0.40 \pm 0.02^{b}$ & $19.25 \pm 0.05^{\mathrm{e}}$ & $3.52 \pm 0.03^{\mathrm{d}}$ & $107.50 \pm 6.61^{\mathrm{ab}}$ & $942.21 \pm 48.08^{b}$ \\
\hline
\end{tabular}

${ }^{\star}$ Mean values with different superscript on the same column are significantly different $(\mathrm{p}<0.05)$. 
The volume expansion of instant Bose ranged from 95.83 to $122.22 \%$ (Table 2). The highest volume expansion was produced by instant Bose that was soaked for 16 hours with the addition of soybeans, and the lowest volume expansion was produced by instant Bose that was soaked for 2 hours with the addition of peanuts. Materials with high porosity and water absorption will produce high volume expansion (Sasmitaloka et al., 2019). According to Husain et al. (2006) soaking the materials in sodium citrate solution can cause their structure to be more porous and starch cell walls to be more exposed, so the water is easily trapped into the granules. This indicates that the longer soaking time in sodium citrate solution, the higher of the volume expansion will be. Instant Bose added with peanuts was not as porous as that added with other types of beans, so the water absorption was blocked and caused low volume expansion.

The hardness of instant Bose ranged from 680.99 to 1192.63 $\mathrm{N}$ (Table 2) with the highest hardness value produced in instant Bose with the addition of peanuts (942.21-1192.63 N), and the lowest hardness value produced in instant Bose with the addition of soybeans (680.99-760.81 N). The hardness value of Bose with the addition of peanuts was close to the hardness value of instant rice according to Chen et al. (2014) which is $1159.54 \mathrm{~N}$. However, all hardness values of instant Bose in this study are higher than that of instant rice, according to Prapluettrakul et al. (2012), namely 275.93-454.62 N. Peanuts have a larger dimension than soybeans and mungbeans resulting in a smaller surface area of water absorption which increases hardness. In addition, the high fat content in peanuts causes the formation of lipid complexes with amylose during cooking, resulting in restricting moisture uptake as a barrier for water migration into the beans, thereby increasing hardness. According to Leethanapanich (2015), fat content affects the texture of cooked rice due to the formation of the amylose-lipid complex. The longer the soaking time, the lower the hardness value of instant Bose is. This is in line with the results of Syanda (2019) study on soaking common beans. This is because the longer length of soaking time increases imbibition capacity and water absorption of beans (Jomduang \& Bunthawong, 2019).

\subsection{Selection the best treatment for sensory analysis}

Based on above data, the best treatment was selected using the effectiveness index method (DeGarmo et al., 1984) for each type of beans, namely selection based on the highest total result value (Nh). The highest rating is determined from the highest score (Nh). Based on Table 3, it is known that the best length of soaking time is 16 hours for each type of bean. The three samples were then tested sensory and compared with conventional Bose (non-instant).

\subsection{Sensory evaluation}

The sensory analysis was carried out on instant Bose samples with the addition of soybeans, mungbeans and peanuts with a soaking time of 16 hours, which were cooked according to the rehydration time. The sensory evaluation result is shown in Figure 1. The scores given by the panelists were similar. The acceptability of colors had no significant effect $(p>0.05)$ according to the types of the added beans. However, the different types of added beans had significantly affected on the acceptability of flavor, taste, texture and overall. The acceptability of flavor was neutral
Table 3. The effectiveness index of instant Bose.

\begin{tabular}{ccc}
\hline \multicolumn{2}{c}{ Treatment } & \multirow{2}{*}{ Result value (Nh) } \\
\cline { 1 - 2 } Types of beans & Soaking time (hour) & 0.29 \\
Soybeans & 2 & 0.43 \\
& 9 & $\mathbf{0 . 7 1}$ \\
Mungbeans & $\mathbf{1 6}$ & 0.29 \\
& 2 & 0.45 \\
Peanuts & 9 & $\mathbf{0 . 7 1}$ \\
& $\mathbf{1 6}$ & 0.29 \\
& 2 & 0.56 \\
& 9 & $\mathbf{0 . 6 3}$ \\
\hline
\end{tabular}

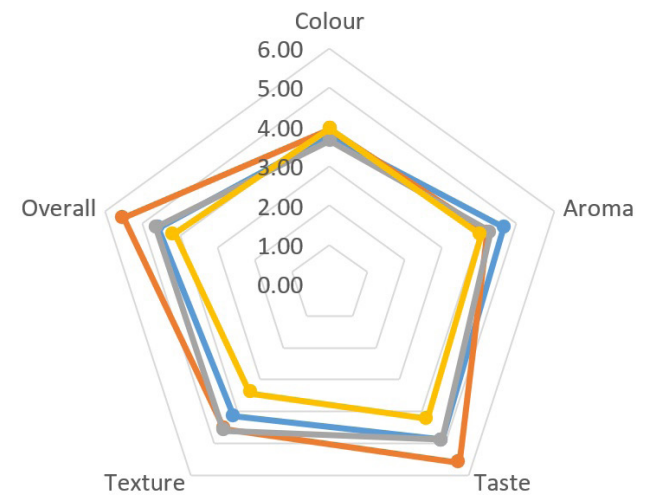

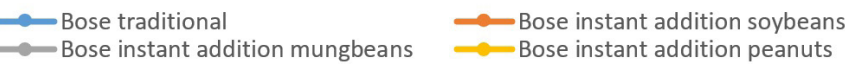

Figure 1. Sensory evaluation of instant Bose with the addition of different types of beans.

(4). Consumption of dried beans is rarely limited because they have a rich (Nyombaire et al., 2011). The panelists accepted the flavor of Bose which indicated that type beans can be added to the Bose especially when the autoclave process could minimize the flavor of the beans.. In this study, the panelists awarded 3 (neither dislike) to 4 (neutral) for all treatments in terms of the color. The panelists fail to award higher score because they are unfamiliar with Bose. Instant Bose added with soybeans had slightly higher scores for taste and overall. These results indicated that panelists preferred instant Bose added by soybeans.

\section{Conclusion}

The addition of soybeans, mungbeans, and peanuts increases the nutritional content of instant Bose, but the longer soaking time decreases its nutritional content and affects its physical properties. The longer the soaking time, the shorter the rehydration time and the softer the texture will be. Instant Bose with 16 hours of soaking treatment is the chosen treatment. Based on the sensory test, instant Bose with the addition of soybeans is preferred compared to conventional Bose. The addition of several types of beans and 16-hour soaking time have the potential for improving the nutrition, handling characteristics and functional properties such as rapid rehydration, thereby increasing the potential of instant Bose to become a ready-to-eat traditional Indonesian product. 


\section{Acknowledgements}

We would like to express our gratitude to the Ministry of Research and Technology for funding this research, the Research Center for Appropriate Technology of Indonesian Institute of Sciences, and Universitas Sebelas Maret for providing facilities and assisting this research.

\section{References}

Balasubramanian, S., Borah, A., Singh, K. K., \& Patil, R. T. (2012). Effect of selected dehulled legume incorporation on functional and nutritional properties of protein enriched sorghum and wheat extrudates. Journal of Food Science and Technology, 49(5), 572-579. http://dx.doi.org/10.1007/s13197-010-0209-8. PMid:24082268.

Berk, Z. (2009). Food Process Engineering and Technology (pp. 459-510). London: Elsevier, Academic Press. http://dx.doi.org/10.1016/ B978-0-12-373660-4.00022-3

Bhagyawant, S. S., Bhadkaria, A., Narvekar, D. T., \& Srivastava, N. (2019). Multivariate biochemical characterization of rice bean (Vigna umbellata) seeds for nutritional enhancement. Biocatalysis and Agricultural Biotechnology, 20, 101193. http://dx.doi.org/10.1016/j. bcab.2019.101193.

Bourlieu-Lacanal, C., Guillard, V., Vallès-Pamiès, B., \& Gontard, N. (2007). Edible moisture barriers: materials, shaping techniques and promises in food product stabilization. Food Materials Science: Principle and Practice. 2007, 547-577.

Bui, L., \& Coad, R. (2015). Improving the quality of freeze dried rice: initial evaluations. Camberra: Land Divison DSTL Defence Science and Technology Organisation.

Chen, X., Qian, P., Zhang, X. J., Liu, F. N., \& Lu, R. R. (2014). Improving instant rice quality by novel combined drying. Drying Technology, 32(12), 1448-1456. http://dx.doi.org/10.1080/07373937.2014.900503.

Dahiya, P. K., Linnemann, A. R., Van Boekel, M. A. J. S., Khetarpaul, N., Grewal, R. B., \& Nout, M. J. R. (2015). Mung bean: technological and nutritional potential. Critical Reviews in Food Science and Nutrition, 55(5), 670-688. http://dx.doi.org/10.1080/10408398.20 12.671202. PMid:24915360.

DeGarmo, E. P., Canada, J. R., \& Sullivan, W. G. (1984). Engineering Economy (7th ed.). New York: New York Macmillan Pub. Coy. Inc.

Ekafitri, R., Wijayanti, F., \& Kumalasari, R. (2016). Pengembangan produk beras jagung instan: kajinan penerimaan sensoris, karakteristik kimia, dan analisis biaya produksi (product development of instant rice corn: study of sensory evaluation, chemical characteristics, and cost of production). PANGAN, 25(3), 157-170.

El-Adawy, T. A., Rahma, E. H., El-Bedawy, A. A., \& Sobihah, T. Y. (2000). Effect of soaking process on nutritional quality and protein solubility of some legume seeds. Nahrung - Food, 44(5), 339-343.

ElMaki, H. B., AbdelRahaman, S. M., Idris, W. H., Hassan, A. B., Babiker, E. E., \& El Tinay, A. H. (2007). Content of antinutritional factors and $\mathrm{HCl}$-extractability of minerals from white bean (Phaseolus vulgaris) cultivars: Influence of soaking and/or cooking. Food Chemistry, 100(1), 362-368. http://dx.doi.org/10.1016/j.foodchem.2005.09.060.

Eltayeb, L. F., Mohamed, M. A. S., \& Fageer, A. S. M. (2017). Effect of soaking on nutritional value of sorghum (Sorghum bicolor L). International Journal of Scientific Research, 6(11), 1360-1365.

Fernandes, A. C., Nishida, W., \& Proença, R. P. C. (2010). Influence of soaking on the nutritional quality of common beans (Phaseolus vulgaris L.) cooked with or without the soaking water: A review. International Journal of Food Science \& Technology, 45(11), 22092218. http://dx.doi.org/10.1111/j.1365-2621.2010.02395.x.
Gasong, L. S. (2019). Pengembangan produk jagung bose instan diperkaya zat besi untuk penanganan anemia remaja putri di Kupang [Product development of iron fortified instant bose corn (IBC) and its efficacy on addressing anemia among adolescent girls in Kupang]. Bogor: Bogor Agricultural University.

Gasong, L. S., Damayanthi, E., Marliyanti, S. A., \& Martianto, D. (2018). Local food preferences for adolescents girls in Kupang, East Nusa Tenggara, Indonesia. Scholars Journal of Arts, Humanities and Social Sciences, 6(11), 2140-2144.

Gondwe, T. M., Alamu, E. O., Mdziniso, P., \& Maziya-Dixon, B. (2019). Cowpea (Vigna unguiculata (L.) Walp) for food security: an evaluation of end-user traits of improved varieties in Swaziland. Scientific Reports, 9, 15991. http://dx.doi.org/10.1038/s41598-01952360-w. PMid:31690778.

Gunathilake, K. G. T., Herath, T., \& Wansapala, J. (2016). Comparison of physicochemical properties of selected locally available legumes varieties (Mung bean, Cowpea and Soybean). Potravinárstvo, 10(1), 424-430. http://dx.doi.org/10.5219/631.

Husain, H., Muhtadi, T. R., Sugiyono, \& Haryanto, B. (2006). Pengaruh metode pembekuan dan pengeringan terhadap karakteristik grits jagung instan. Jurnal Teknologi dan Industri Pangan, 17(3), 189-196.

Ishartani, D., Sagita, R., \& Praseptiangga, D. (2019). Chemical characteristics of composite flour based on white corn and okara. IOP Conference Series. Materials Science and Engineering, 633(1), 012043. http://dx.doi.org/10.1088/1757-899X/633/1/012043.

Jomduang, S., \& Bunthawong, O. (2019). Optimal pre-treatment processes for microwavable puffed Job's tears grains. Chiang Mai University Journal of Natural Sciences, 18(1), 107-121. http://dx.doi. org/10.12982/CMUJNS.2019.0009.

Kumalasari, R., Senyoningrum, F., \& Ekafitri, R. (2018). Karakteristik fisik dan sifat fungsional beras jagung instan dengan variasi penambahan jenis serat dan lama pembekuan. TEKNOLOGI PANGAN: Media Informasi Dan Komunikasi Ilmiah Teknologi Pertanian, 9(1), 37-48.

Leahu, A., \& Rosu, A. I. (2014). Effect of soaking on the cooking quality and colour parameters of common beans (Phaseolus Vulgaris L.). Food and Environment Safety, 13(3), 244-251.

Leethanapanich, K. (2015). Impacts offeedstock and parboiling conditions on quality characteristics of parboiled rice. Fayetteville: University of Arkansas.

Luna, P., Herawati, H., Widowati, S., \& Prianto, A. B. (2015). Pengaruh kandungan amilosa terhadap karaktersitik fisik dan organoleptik nasi instan. Jurnal Penelitian Pascapanen Pertanian, 12(1), 1-10. http://dx.doi.org/10.21082/jpasca.v12n1.2015.1-10.

Narsih, Yunianta, \& Harijono. (2012). The study of germination and soaking time to improve nutritional quality of sorghum seed. International Food Research Journal, 19(4), 1429-1432.

Nyombaire, G., Siddiq, M., \& Dolan, K. D. (2011). Physico-chemical and sensory quality of extruded light red kidney bean (Phaseolus vulgaris L.) porridge. Lebensmittel-Wissenschaft + Technologie, 44(7), 1597-1602. http://dx.doi.org/10.1016/j.lwt.2011.02.016.

Phukasmas, P., \& Songsermpong, S. (2019). Intant rice process development: effect of rice cooking methods on the quality of jasmine instant rice dried by industrial microwave oven. Journal of Microbiology, Biotechnology and Food Sciences, 9(2), 330-334. http://dx.doi.org/10.15414/jmbfs.2019.9.2.330-334.

Prapluettrakul, B., Tungtrakul, P., Panyachan, S., \& Limsuwan, T. (2012). Development of Instant Rice for Young Children. Science, Engineering and Health Studies, 6(1), 49-58.

Prasert, W., \& Suwannaporn, P. (2009). Optimization of instant jasmine rice process and its physicochemical properties. Journal 
of Food Engineering, 95(1), 54-61. http://dx.doi.org/10.1016/j. jfoodeng.2009.04.008.

Puspita, D., Sinaga, J. P. N., \& Tanadi, E. (2017). Kacang nasi (Vigna umbellata) sebagai bahan brownies untuk diversifikasi pangna lokal di NTT [Rice beans (Vigna umbellata) as brownies for local food diversification in NTT]. In S. Wahyuningrat (Eds.), Prosiding Seminar Nasional "Pengembangan Sumber Daya Perdesaan dan Kearifan Lokal Berkelanjutan (pp. 710-716). Purwokerto: Jenderal Soedirman University in Indonesia.

Rosyid, N. (2014). Pandangan petani Alor mengenai Bose dan Ketema dalam konteks strategi ekologis dan kultural. JANTRA, 9(1), 1-27.

Sasmitaloka, K. S., Widowati, S., \& Sukasih, E. (2019). Effect of freezing temperature and duration on physicochemical characteristics of instant rice. In Setyadjit, S. Yuliani, E. S. Iriani, P. J. Batt, \& O. Gibert, (Eds.), IOP Conf. Series: Earth and Environmental Science 309 (p. 012043). Bali: IOP Science. http://dx.doi.org/10.1088/1755$1315 / 309 / 1 / 012043$

Srichamnong, W., Thiyajai, P., \& Charoenkiatkul, S. (2016). Conventional steaming retains tocols and c-oryzanol better than boiling and frying in the jasmine rice variety Khao dok mali 105. Food Chemistry, 191, 113-119.
Syanda, J. S. (2019). The effects o physical properties of common bean (phaseolus vulgaris L.) varieties on soaking and cooking time. Kitui County: South Eastern Kenya University.

The National Standardization Agency of Indonesia. (1992). SNI 012891-1992: Cara uji makanan dan minuman [SNI 01-2891-1992: food and beverages analysis]. Jakarta: BSN.

Verma, A., Kushwaha, A., Kumar, A., \& Baghel, S. S. (2019). Physicochemical properties and nutritional composition of improved varieties of grain cowpea grown in Pantnagar. Journal of Pharmacognosy and Phytochemistry, (SP5), 334-338.

Widjajaseputra, A. I., Widyastuti, T. E. W., \& Trisnawati, C. Y. (2019). Potency of mung bean with different soaking times as protein source for breastfeeding women in Indonesia. Food Research, 3(5), 501-505. http://dx.doi.org/10.26656/fr.2017.3(5).105.

Wikandari, R., Utami, T. A. N., Hasniah, N., \& Sardjono. (2020). Chemical, nutritional, Physical and sensory characterization of tempe made from various underutilized legumes. Pakistan Journal of Nutrition, 19(4), 179-190. http://dx.doi.org/10.3923/pjn.2020.179.190.

Yasin M. H. G., Langgo, W., \& Faesal. (2014). Jagung berbiji Putih sebagai bahan pangan pokok alternatif. Iptek Tanaman Pangan, 9(2), 108-117. 